\title{
Suspension feeding in marine sponges Halichondria panicea and Haliclona urceolus: effects of temperature on filtration rate and energy cost of pumping
}

\author{
H. U. Riisgård ${ }^{1}$, S. Thomassen ${ }^{1}$, H. Jakobsen ${ }^{1}$, J. M. Weeks ${ }^{1}$, P. S. Larsen ${ }^{2}$ \\ ${ }^{1}$ Institute of Biology, Odense University, DK-5230 Odense M, Denmark \\ ${ }^{2}$ Department of Fluid Mechanics, Technical University of Denmark, DK-2800 Lyngby, Denmark
}

\begin{abstract}
Filtration rate (measured as clearance of algal cells) was measured at different temperatures in the sponge Halichondria panicea. An increase in water temperature from 6 to $12{ }^{\circ} \mathrm{C}$ caused the mean filtration rate to increase $4.3 \pm 2.3$ times. This value was higher than previously found for other marine ciliary suspension-feeding animals. Filtration rate at $12{ }^{\circ} \mathrm{C}$ was also measured in Haliclona urceolus by means of an indirect clearance method in addition to a direct technique for measuring pumping rate. It was found that the 2 sponge species had near-identical filtration rates, with maximum rates of approximately $60 \mathrm{ml} \mathrm{min}{ }^{-1}(\mathrm{~g} \text { dry weight })^{-1}$ at $12^{\circ} \mathrm{C}$. The normal pump pressure, or operating point $O_{p}$, of a standard sponge (based on our own measurements and calculations from literature data for a $0.1 \mathrm{~g}$ dry weight Haliclona sp.) was estimated as the sum of main contributions to head losses along the flow path from entry (ostia) to exit (osculum). The head losses were as follows: ostia $0.0373 \mathrm{~mm} \mathrm{H}_{2} \mathrm{O}$; inhalant canal 0.1205 to $0.013 \mathrm{~mm} \mathrm{H}_{2} \mathrm{O}$; prosopyles 0.1153 to $0.02321 \mathrm{~mm} \mathrm{H}_{2} \mathrm{O}$; collar-filter $0.122 \mathrm{~mm}$ $\mathrm{H}_{2} \mathrm{O}$; exhalant canals = inhalant canals; and osculum $0.1576 \mathrm{~mm} \mathrm{H}_{2} \mathrm{O}$. The (maximal) $\mathrm{O}_{\mathrm{p}}$ was found to be $0.673 \mathrm{~mm} \mathrm{H}_{2} \mathrm{O}$ and the power output $P_{\mathrm{p}}$ from the sponge pump was $0.677 \mu \mathrm{W}$. The pump work, defined as $P_{\mathrm{p}} R^{-1}$ where $R$ is the respiratory output, was $0.85 \%$. The low energy cost of filtration and the temperature effect are discussed and compared with recent data for other ciliary suspension feeders. It is argued that passive current-induced filtration may be of insignificant importance for sponges.
\end{abstract}

\section{INTRODUCTION}

It is agreed that in order to meet their food requirements, suspension-feeding marine invertebrates must generally filter large volumes of water with a high retention efficiency of small particles of suspended food, often only a few microns in diameter (Jørgensen 1966). The energy cost of water pumping has been a debated subject for many years. An intuitive or superficial consideration may lead to the supposition that suspension feeding is an expensive condition of life due to 'the cost of a large metabolic outlay for generating water flow" (LaBarbera 1984) and is therefore 'a marginal business' (Vogel 1978a). However, this seems to be an erroneous belief (Foster-Smith 1976, Jørgensen 1983, Jørgensen et al. 1984, Fenchel 1986, Riisgård \& Ivarsson 1990).
During recent years a number of biological pump and filtersystems in marine suspension-feeding invertebrates (bivalves, polychaetes, ascidians) have been studied and characterized, especially regarding the power output of these biological pumps in relation to total metabolic power output (Jørgensen et al. 1986, Jørgensen \& Riisgård 1988, Jørgensen et al. 1988, Riisgård 1988, Riisgård 1989, Riisgård \& Ivarsson 1990, Riisgård 1991), but temperature effects on pumping rates have been investigated also (Jorgensen et al. 1990, Petersen \& Riisgård 1992, Riisgård et al. 1992) . These studies have shown that the energy cost of water pumping is unlikely to be a restricting factor for the distribution and success of suspension-feeding animals in the marine environment. However, the pump and filter systems in different species seem to be specifically dimensioned to the biotope to which the species 
are adapted. Furthermore, such studies have shown that no simple and common relationship exists between temperature and pumping rate, not even in ciliary suspension feeders (Petersen \& Riisgård 1992).

To obtain a more complete picture of the energy cost of biological fluid-pumps in different taxonomic groups of suspension-feeding animals, and to approach a more fundamental understanding of temperature effects (biological versus physical), especially in ciliary pumps, it has been of interest to study marine sponges. Sponges are sedentary, filter-feeding metazoans in which the entire body is specialized to suspension feeding, and the basic principles for water pumping and particle retention are the same in all demosponges. In general, water enters the body of the sponge through numerous small openings (ostia) on the surface, flows through a branched inhalant canal system to the water pumping units, the choanocyte chambers, within which there are numerous choanocytes, each with a beating flagellum and a collar filter which efficiently retains small suspended particles, including free living bacteria, and colloidal organic matter (Reiswig 1975, Bergquist 1978, Frost 1978, Jørgensen 1983, Simpson 1984). The filtered water leaves the choanocyte chamber through an opening into the exhalant canal system that merge into 1 or more openings (oscula) on the surface.

The present paper examines the effects of temperature on filtration rate and attempts to assess the energy output of the sponge pump in relation to total metabolic output.

\section{MATERIALS AND METHODS}

The experiments were performed on 2 demosponges collected by divers in Romsø Sund east of Hindsholm, Funen, Denmark, from the surface of boulders at 3 to $4 \mathrm{~m}$ water depth during March 1992 (Halichondria panicea) and at $12 \mathrm{~m}$ depth during July and August 1992 (Haliclona urceolus). The sponges (always kept cool and under water throughout manipulation) were transported to the nearby Fjord Biological Laboratory, Kerteminde. A number of $H$. panicea colonies were individually suspended on $10 \mathrm{~cm}$ long nylon threads (Barthel \& Theede 1986$)$ in an aquarium with flow-through seawater $\left(6.5^{\circ} \mathrm{C}, 22 \%\right.$ salinity $)$ until filtration rate measurements could be performed. All measurements on $H$. urceolus were made within $12 \mathrm{~h}$ of collection.

Filtration rate was measured as the volume of water cleared of flagellate cells (Rhodomonas sp., almost spherical cells, about $6.5 \mu \mathrm{m}$ in diameter) which are retained by the sponges with $100 \%$ efficiency (Reiswig 1971). Several hours prior to each clearance experiment the individual sponge colonies were suspended in the centre of a $1 \mathrm{l}$ glass beaker containing $900 \mathrm{ml}$ strongly aerated seawater, in a temperature-adjustable water bath. Flagellate cells were added (usually about 5000 cells $\mathrm{ml}^{-1}$ ) and the reduction in number of particles as a function of time was followed by removing water samples $(15 \mathrm{ml})$ every 5 or $10 \mathrm{~min}$ and measuring the particle concentration of each sample with an Elzone 180 electronic particle counter, taking the mean value of 3 measurements, each using $0.25 \mathrm{ml}$ of the sample, as a standard. The remainder of the sample was returned to the experimental beaker to avoid a significant reduction in seawater volume $\left(V_{\mathrm{w}}\right)$ during the experiment. A beaker without a sponge colony served as the control. Clearance (c) was determined from the exponential reduction in algal cell concentration as a function of time (verified as a straight regression line on a semi-log plot) using the formula:

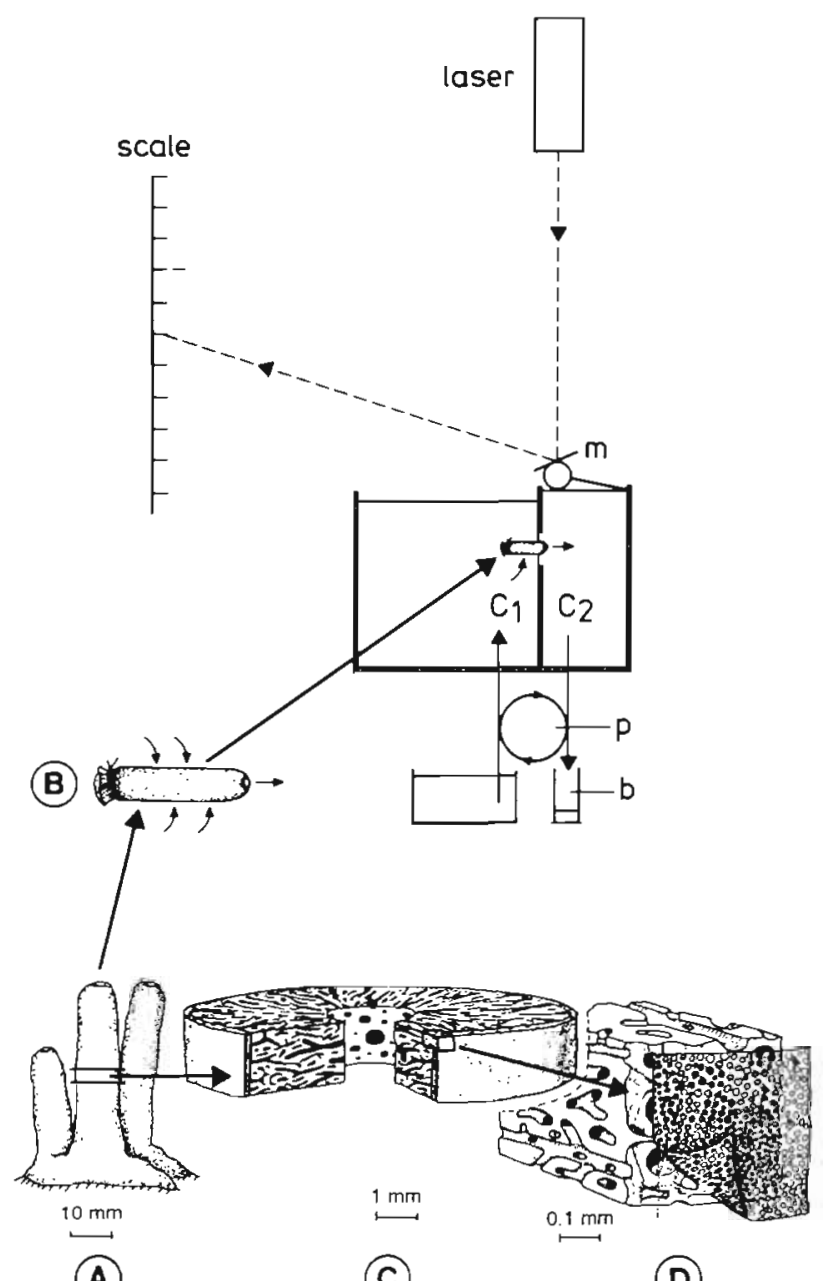

(4)

(C)

(D)

Fig. 1. Diagram of set-up for direct measurement of pumping rate in a branch cut from a sponge colony (A and B). (C) and (D) show organization of the aquiferous system in Haliclona permollis (from Reiswig 1975) 


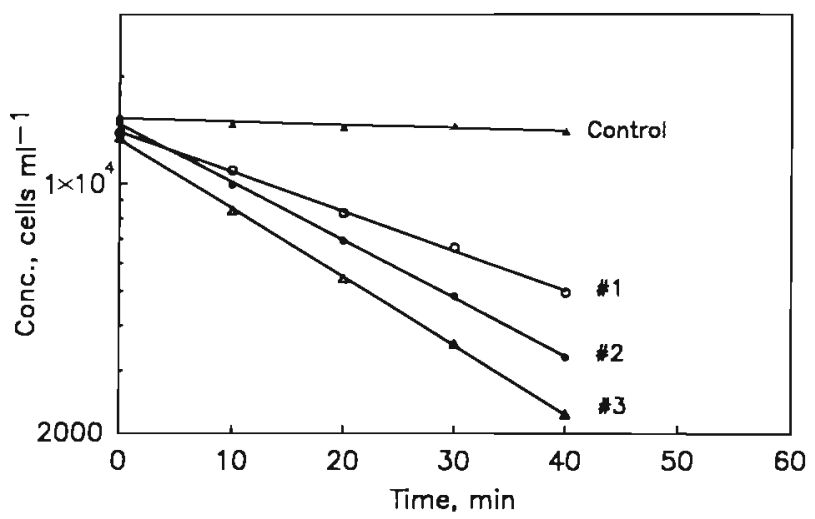

Fig. 2. Halichondria panicea. Reduction of algal cells due to grazing by Sponges \#1, \#2 and \#3 suspended in beakers with $900 \mathrm{ml}$ aerated seawater. The filtration rates, expressed by the slope of the regression lines, are shown in Table 1

$c=\left(V_{\mathrm{w}} / t\right) \ln \left(C_{0} / C_{t}\right)$ where $C_{0}$ and $C_{t}$ are the algal concentrations at time 0 and time $t$, respectively, calculated from the regression equation.

Direct measurements of pumping rates were performed on Haliclona urceolus using the technique described by Riisgåd (1988) for direct measurement of pumping rates in the ascidian Styela clava. A 5 l aquarium was divided into 2 chambers ( $\mathrm{C} 1$ and $\mathrm{C} 2$ ) by a membrane (cut from a latex surgical glove) into which a circular hole had been punched. A single sponge branch cut from a sponge colony without lateral oscula, was tied off at one end by means of sewing thread to make a 1-way water outflow through the osculum. The other end was inserted about $3 \mathrm{~mm}$ through the latex hole so that the membrane separated the inhalant and exhalant water (see Fig. 1). A shunt connected the 2 chambers when open. The water level in the exhalant chamber (C2) was monitored with a laser beam striking a mirror that was fixed on a tethered floating ping-pong ball. The mirror reflected the laser onto a scale approximately $8 \mathrm{~m}$ from the mirror. When the sponge pumped water from $\mathrm{C} 1$ to $\mathrm{C} 2$ with the shunt closed, the water level could be kept at zero or at a known imposed back pressure maintained by means of a peristaltic pump that returned water from $\mathrm{C} 2$ to $\mathrm{C} 1$. The pumping rate of the calibrated peristaltic pump was identical to the pumping rate of the sponge. Only data obtained at zero back pressure are reported in the present work, but the simultaneously determined back-pressure pumping-rate characteristics will be presented in another paper dealing with an analysis of the sponge pump (Larsen \& Riisgârd unpubl.).

After the experiments, the sizes of the individual sponge colonies were expressed in several ways: volume $\left(V_{s}, m l\right.$ of displaced water in a graduated cylinder glass), dry weight (DW, $100^{\circ} \mathrm{C}, 24 \mathrm{~h}$ ), ash free dry

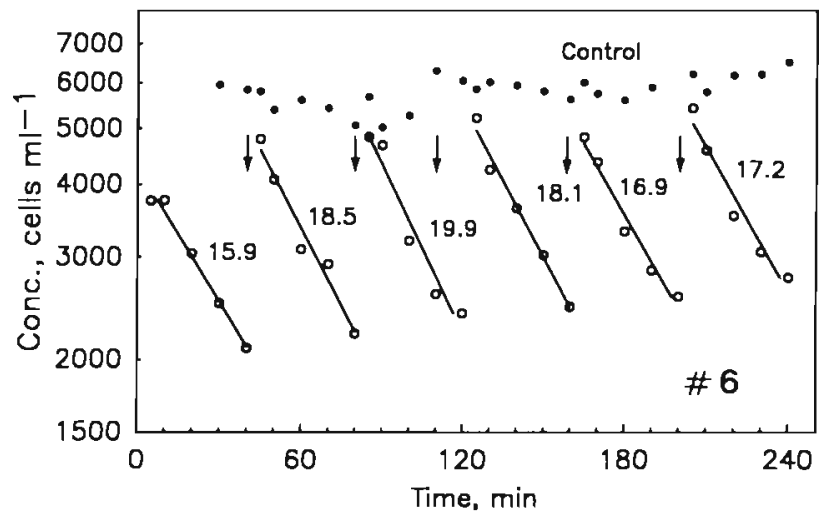

Fig. 3. Halichondria panicea. Reduction of algal cells due to grazing of Sponge \#6 in a beaker with $900 \mathrm{ml}$ seawater $\left(12^{\circ} \mathrm{C}\right.$ ) and a control beaker without sponge. Arrows indicate additions of algal suspension to the experimental beaker with sponge. The slope of regression lines represents the sponge's filtration rate $\left(\mathrm{ml} \mathrm{min}^{-1}\right.$, indicated for each line)

weight (AFDW, $7 \mathrm{~h}$ ashing of ground DW samples in a muffle furnace at $500^{\circ} \mathrm{C}$ ) and total nitrogen (N). The nitrogen analyses were performed on a Carlo Erba EA1108 CHNS-analyzer with Euger 200 software. Sample weights were determined on a Mettler ME22 microbalance.

\section{RESULTS AND DISCUSSION}

\section{Filtration rate and effects of temperature on Halichondria panicea}

The method and treatment of measured data used for estimating filtration rate (i.e. clearance of algal cells retained by the Halichondria panicea colony with $100 \%$ efficiency) is illustrated in Figs. 2 \& 3. In Fig. 3 the filtration rate of $H$. panicea was near-constant, 17.8 $\pm 1.4 \mathrm{ml} \mathrm{min}^{-1}$, throughout the $4 \mathrm{~h}$ experimental period. Filtration rates at different temperatures were measured using the same procedure as used for experiments shown in Fig. 3, except that the temperature of the water bath was increased or decreased between each new algal addition. The temperature studies are depicted in Figs. 4, 5 \& 6. A significant temperature effect was noticed, being most pronounced in Sponge \#9 that underwent an increase in filtration rate of approximately 10 times following a temperature rise from 6 to $15^{\circ} \mathrm{C}$ (Fig. 6)

The size and measured filtration rates at $12{ }^{\circ} \mathrm{C}$ for all Halichondria panicea used in the present work are presented in Table 1. The relationships between $V_{\mathrm{s}}$ and DW and AFDW, respectively, are shown in Fig. 7. Both DW and AFDW show a similar high degree of correlation with $V_{s}$, and the same applies for total 

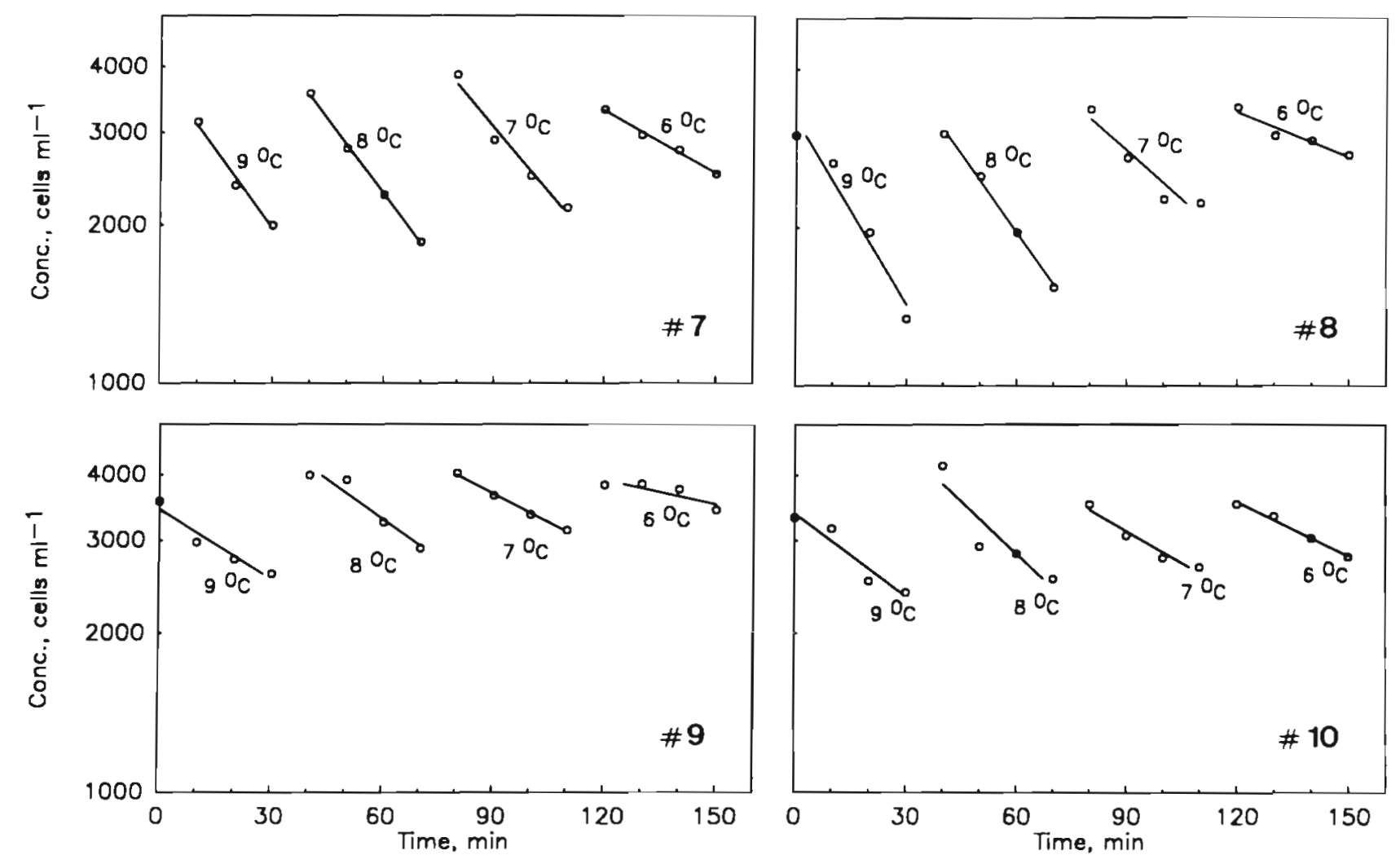

Fig. 4. Halichondria panicea. Clearance of algal cells at different temperatures in 4 parallel experiments with Sponges \#7, \#8, \#9 and \#10. Size of colonies and calculated filtration rates are shown in Table 1
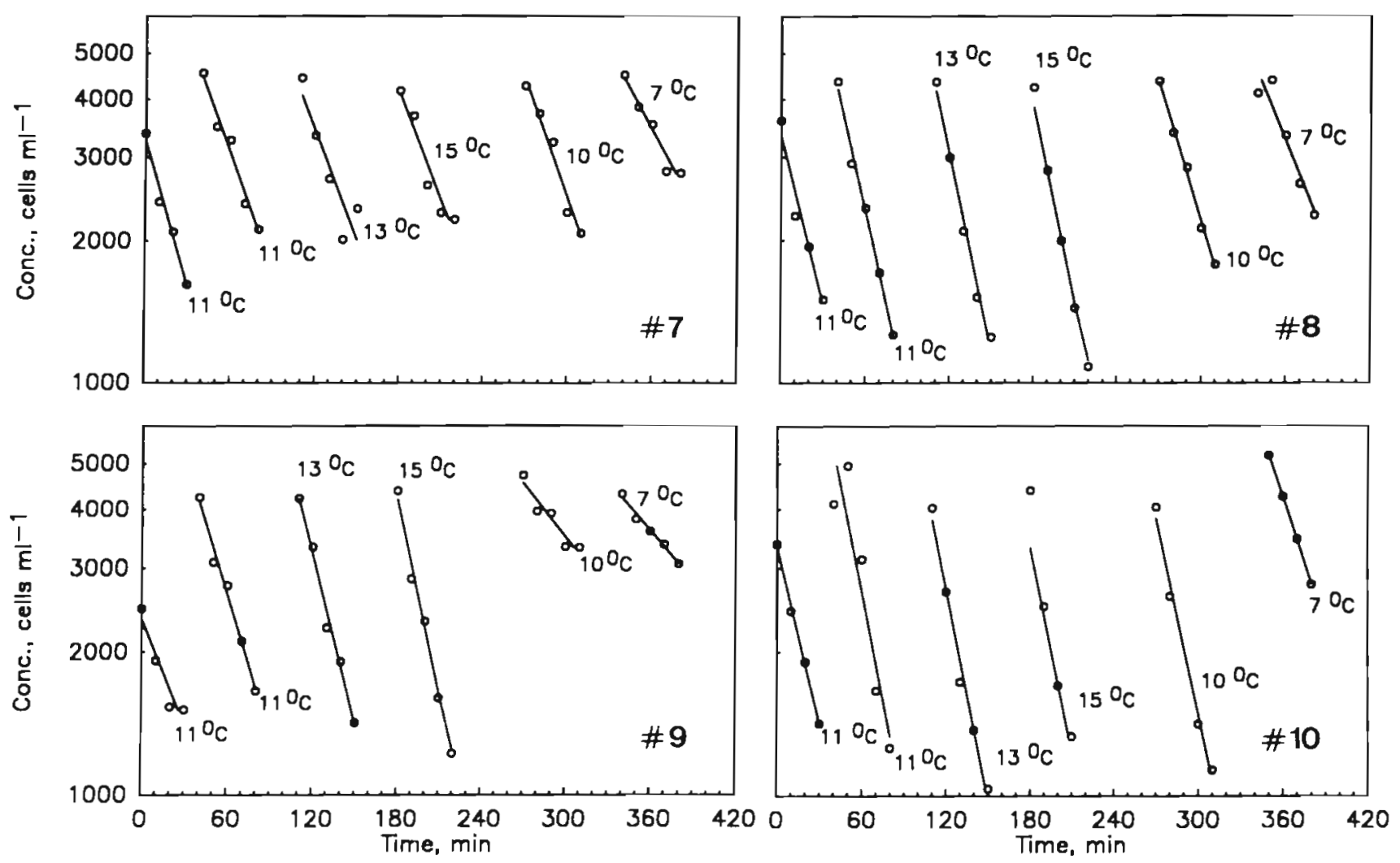

Fig. 5. Halichondria panicea. Clearance of algal cells at different temperatures in 4. paralle] experiments with Sponges \#7, \#8, \#9 and \#10 

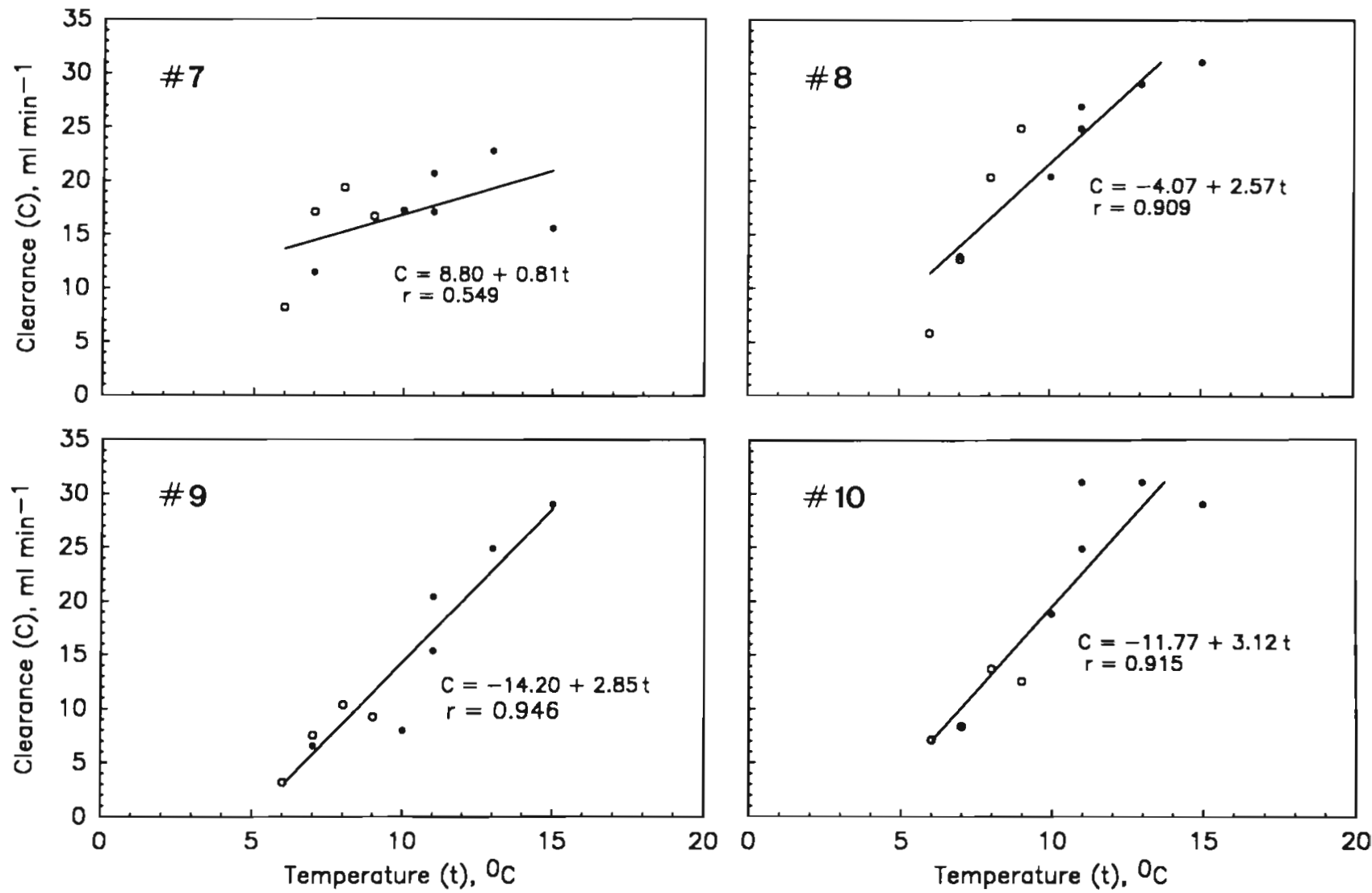

Fig. 6. Halichondria panicea. Filtration rate (= clearance) of Sponges \#7, \#8, \#9 and \#10 [data from Fig. 4 (open symbols) and Fig. 5 (closed symbols), see also Table 1 j as a function of temperature. Regression lines and their equations are shown

nitrogen content (not shown). The dry weight specific clearance $\left[c_{\mathrm{DW}}, \mathrm{ml}(\mathrm{g} \mathrm{DW})^{-1}\right]$ as a function of $V_{\mathrm{S}}(\mathrm{ml})$ may be expressed as a linear function: $C_{D W}=45.23-$ $2.26 \mathrm{~V}, \mathrm{r}=-0.632$, or as a power function: $C_{\mathrm{DW}}=124.9$ $\mathrm{V}^{-087}, \mathrm{r}=-0.708$. The correlation coefficient is higher for the power function, but it ought to be stated that the power function allometry usually found in metazoans may not necessarily be valid for sponges with their unique construction, often classified in a separate subkingdom, the Parazoa. Thus, if the density of choanocyte chambers is uniform, weight-specific clearance should not be expected to decrease with size. But this is apparently the case as also shown previously by Reiswig (1974) and Frost (1980). One possible explanation of decreasing weight-specific clearance could be the result of fewer living choanocytes per unit of colony volume in larger (presumably older) sponges.

Total nitrogen content may be regarded as a measure of the amount of the total cell mass, and thus of the number of choanocytes. One should therefore expect the filtration rate per $\mathrm{mg} \mathrm{N}$ to be constant and independent of sponge size. From Table 1 it is seen that this is apparently not the case because filtration rate varies between 0.3 and $1.0 \mathrm{ml}(\mathrm{mg} \mathrm{N})^{-1}$. Thus, the observed differences between different colonies are difficult to explain. It is well known that sponges are sensitive to laboratory conditions, and the lower filtration rates in e.g. Sponges \#4 and \#7 may reflect such sub-optimal conditions. The highest filtration rate per mg N 10.95 $\mathrm{ml} \mathrm{min}^{-1}$ ) was found in Sponge $\# 10$ (Table 1), which may be compared to $1.08 \mathrm{ml} \mathrm{min}^{-1}\left(\mathrm{mg} \mathrm{N}^{-1}\right.$ measured by Jørgensen (1949). Expressed on the basis of g AFDW the filtration rate was $86.4 \mathrm{ml} \mathrm{min}^{-1}$ which may be compared to the near identical rate of $79.8 \mathrm{ml} \mathrm{min}^{-1}$ reported for Halichondria panicea by Jørgensen (1955).

In order to cover minimal energy requirements, as assessed from rates of oxygen consumed, marine suspension feeders are required to filter more than $10 \mathrm{l}$ of water per ml of oxygen consumed (Jørgensen 1975). Respiration rate $\left[R: \mathrm{ml} \mathrm{O}_{2}(\mathrm{~g} A F D W)^{-1} \mathrm{~h}^{-1}\right]$ in Halichondria panicea has been measured at different temperatures $\left(T,{ }^{\circ} \mathrm{C}\right)$ by Barthel \& Theede (1986), and is presented in Table 1 in Barthel (1988). From this table the following equation can be calculated: $\log R=$ $-0.884+0.046 \times T(\mathrm{r}=1.000)$. At $12^{\circ} \mathrm{C}$ the respiration rate of $H$. panicea can be estimated as $0.466 \mathrm{ml} \mathrm{O}_{2} \mathrm{~h}^{-1}$. With a filtration rate of $86.4 \mathrm{ml} \mathrm{min} \mathrm{min}^{-1}$ (\#10, Table 1 ) it 
Table 1. Halichondria panicea. Size ( $V_{s}$ volume), dry weight (DW), ash free dry weight (AFDW) and nitrogen (N) content of dry weight matter, and filtration rates of sponge colonies at $12^{\circ} \mathrm{C}$ (measured as clearance of $6.3 \mu \mathrm{m}$ Rhodomonas sp. algal cells). Clearance at $12^{\circ} \mathrm{C}$ for Colonies $\# 7$ to $\# 10$ have been estimated from the regression equations shown in Fig. 6

\begin{tabular}{|c|c|c|c|c|c|c|c|c|c|}
\hline \multirow[t]{2}{*}{$\begin{array}{c}\text { Colony } \\
\#\end{array}$} & \multirow[t]{2}{*}{$\begin{array}{c}V_{\mathrm{s}} \\
(\mathrm{ml})\end{array}$} & \multirow[t]{2}{*}{$\begin{array}{l}\text { DW } \\
(\mathrm{g})\end{array}$} & \multirow[t]{2}{*}{$\begin{array}{c}\text { AFDW } \\
(g)\end{array}$} & \multirow[t]{2}{*}{$\begin{array}{c}\mathrm{N} \\
(\mathrm{mg})\end{array}$} & \multicolumn{5}{|c|}{$\begin{array}{c}\text { Filtration rate } \\
\text { ml of water cleared per min, per }\end{array}$} \\
\hline & & & & & colony & $\mathrm{ml}$ sponge & gDW & g AFDW & $m g N$ \\
\hline 1 & 4.0 & 0.299 & - & - & 12.9 & 3.2 & 43.1 & - & - \\
\hline 2 & 6.0 & 0.509 & - & - & 18.9 & 3.2 & 37.1 & - & - \\
\hline 3 & 4.5 & 0.371 & - & - & 22.3 & 5.0 & 60.1 & - & - \\
\hline 4 & 4.4 & 0.562 & 0.183 & 22.0 & 7.2 & 1.6 & 12.8 & 39.3 & 0.3 \\
\hline 5 & 6.0 & 0.813 & 0.295 & 26.5 & 19.6 & 3.3 & 24.1 & 66.4 & 0.7 \\
\hline 6 & 5.8 & 0.686 & 0.232 & 20.7 & 17.8 & 3.1 & 26.0 & 76.7 & 0.9 \\
\hline 7 & 17.0 & 2.093 & 0.651 & 54.6 & 18.5 & 1.1 & 8.8 & 28.4 & 0.3 \\
\hline 8 & 15.0 & 1.961 & 0.653 & 54.5 & 26.8 & 1.8 & 13.7 & 41.0 & 0.5 \\
\hline 9 & 10.0 & 1.485 & 0.383 & 38.0 & 20.0 & 2.0 & 13.5 & 52.2 & 0.5 \\
\hline \multirow[t]{3}{*}{10} & 8.0 & 0.841 & 0.297 & 27.1 & 25.7 & 3.2 & 30.5 & 86.4 & 1.0 \\
\hline & & & & & Mean & 2.7 & 27.0 & 55.8 & 0.6 \\
\hline & & & & & $\pm \mathrm{SD}$ & 1.1 & 16.2 & 21.4 & 0.3 \\
\hline
\end{tabular}

may now be calculated that $86.4 \times 60 / 0.466=111$ of water were filtered per $\mathrm{ml}$ of $\mathrm{O}_{2}$ consumed. The mean value for Sponges \#4 to \#10 was $7.2 \pm 2.8$ l of water filtered per $\mathrm{ml} \mathrm{O}_{2}$ consumed. This value is relatively low compared to the tropical marine sponges Mycale sp. and Tethya crypta, which according to Reiswig (1974) filter 19.6 and $22.8 \mathrm{l}$ per $\mathrm{ml} \mathrm{O}_{2}$ respectively. Values for other marine suspension feeders are, for example 15 to $50 \mathrm{l}$ water per $\mathrm{ml} \mathrm{O}_{2}$ for the bivalve Mytilus edulis (Riisgård et al. 1980), 25 to 50 for the polychaete Chaetopterus variopedatus (Riisgård 1989), and 354 for the polychaete Sabella penicillus (Riisgård \& Ivarsson 1990). These differences probably reflect different adaptations in the shape of the pump capacity as related to retention efficiency, food particle size, and concentration of suspended food particles in the habi-

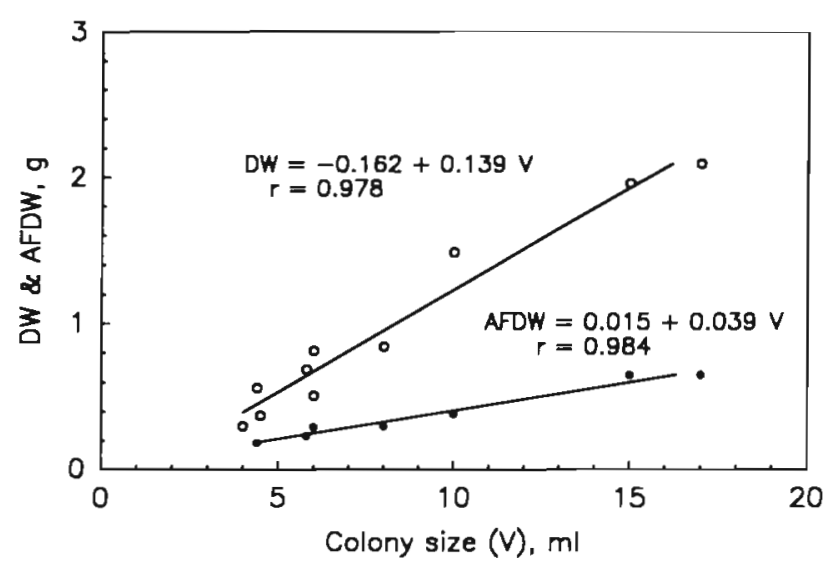

Fig. 7. Halichondria panicea. Filtration rate (= clearance) as a function of colony size (data from Table 1). Regression line and its equation are shown tat. The collar filter in sponges presumably retains particles with $100 \%$ efficiency down to $0.1 \mu \mathrm{m}$ in diameter (Jørgensen 1966, Reiswig 1971). This very high retention efficiency partly explains the lower filtration rates in sponges when compared with, for example, the polychaete $S$. penicillus which retains particles efficiently only above about $4 \mu \mathrm{m}$ in diameter (Jørgensen et al. 1984).

The grazing impact of marine sponge colonies has apparently never been assessed in the field, but in areas with extended sponge populations it is likely that they may exert a considerable role in the control of phytoplankton. The biomass of field populations of Halichondria panicea at Boknis Eck, western Baltic Sea, was recorded by Barthel (1988), who found a maximum of $24 \mathrm{~g} \mathrm{AFDW} \mathrm{m}^{-2}$ at $10 \mathrm{~m}$ water depth in late July $\left(14^{\circ} \mathrm{C}\right)$. With a filtration rate of $107 \mathrm{ml} \mathrm{min}^{-1}$ (g AFDW) $)^{-1}$ at $14^{\circ} \mathrm{C}$ (Sponge \#10. Fig. 6) the population filtration rate could be estimated to be $3.7 \mathrm{~m}^{3} \mathrm{~m}^{-2} \mathrm{~d}^{-1}$ or $37 \%$ of the whole water column per day. Though this value is to an uncertain extent affected by the apparent decrease of the weight-specific filtration rate with colony size, the present estimate indicates that sponges may exert a pronounced grazing impact in certain areas.

\section{Filtration rate in Haliclona urceolus}

Indirectly obtained filtration rates (clearances) measured on Haliclona urceolus are shown in Table 2 , which also shows directly determined filtration rates obtained by means of the direct 'laser ping-pong ball technique'. On a dry weight basis the mean filtration 
Table 2. Haliciona urceolus. Size $\left(V_{\mathrm{s}}\right.$ volume), dry weight (DW), nitrogen ( $N$ ) content of sponge colonies, and filtration rate measured at $12{ }^{\circ} \mathrm{C}$ either by means of the direct technique (Colonies \#1 to \#3 collected in late August) or by the clearance method (Colonies \#4 to \#8 collected in early July)

\begin{tabular}{|c|c|c|c|c|c|c|c|}
\hline $\begin{array}{c}\text { Colony } \\
\# \\
\#\end{array}$ & $\begin{array}{c}V_{\mathrm{s}} \\
(\mathrm{ml})\end{array}$ & $\begin{array}{l}\text { DW } \\
(\mathrm{g})\end{array}$ & $\stackrel{N}{N}$ & colony & $\begin{array}{l}\text { Filtration rat } \\
\text { ml sponge }\end{array}$ & $\begin{array}{l}\text { permin, per } \\
\text { gDW }\end{array}$ & $\mathrm{mg} \mathrm{N}$ \\
\hline 1 & 1.2 & 0.101 & 7.8 & 3.5 & 2.9 & 35.0 & 0.45 \\
\hline 2 & 0.6 & 0.062 & 4.1 & 3.6 & 6.0 & 58.1 & 0.87 \\
\hline 3 & 1.4 & 0.083 & 5.8 & 5.0 & 3.6 & 60.2 & 0.86 \\
\hline 4 & 45 & 3.477 & - & 50.7 & 1.1 & 14.6 & - \\
\hline 5 & 10 & 0.908 & - & 12.3 & 1.2 & 13.6 & - \\
\hline 6 & 9 & 0.763 & - & 19.0 & 2.1 & 24.9 & - \\
\hline 7 & 10 & 0.753 & - & 18.4 & 1.8 & 24.4 & - \\
\hline \multirow[t]{3}{*}{8} & 16 & 1.053 & - & 17.8 & 1.1 & 16.9 & - \\
\hline & & & & Mean & 2.5 & 31.0 & 0.7 \\
\hline & & & & $\pm \mathrm{SD}$ & 1.7 & 18.7 & 0.2 \\
\hline
\end{tabular}

rate of H. urceolus was $31.0 \pm 18.7 \mathrm{ml} \mathrm{min}^{-1}(\mathrm{~g} \mathrm{DW})^{-1}$ (Table 2), compared to $27.0 \pm 16.2 \mathrm{ml} \mathrm{min}^{-1}(\mathrm{~g} \mathrm{DW})^{-1}$ in Halichondria panicea (Table 1). The maximum recorded filtration rate in both sponges was about $60 \mathrm{ml}$ $\min ^{-1}(\mathrm{~g} \mathrm{DW})^{-1}$

\section{Energy cost of pumping}

Parameters of 'standard sponge'

The great similarity of basic anatomic structures of the aquiferous system in demosponges (Reiswig 1975) and near-identical filtration rates in Halichondria panicea and Haliclona urceolus (Tables 1 \& 2) justify definition of a 'standard sponge' (DW $=0.1 \mathrm{~g}$; AFDW = $0.033 \mathrm{~g}$ ) with a maximal filtration rate of $6 \mathrm{ml} \mathrm{min}^{-1}$ (Tables $1 \& 2$ ) and a respiration rate of $15 \mu \mathrm{O}_{2} \mathrm{~h}^{-1}$ at $12{ }^{\circ} \mathrm{C}$. When the temperature $T$ is lowered from 12 to $6^{\circ} \mathrm{C}$ the filtration rate $\left(F, \mathrm{ml} \mathrm{min}^{-1}\right)$ is rectilinearly reduced 4.3 times (Fig. 6), i.e. $F=b T+a$. The relationship between filtration rate and temperature for the 'standard sponge' is given by $F=0.77 T-3.2$. The shape and dimensions of the 'standard sponge' are as follows (based on 'mean' data from the 2 near-identical $H$. urceolus \#1 and \#3): tubular/cylindrical shape $=32$ $\mathrm{mm}$ long, outer diameter $=8.6 \mathrm{~mm}$, diameter of atrium $=2.3 \mathrm{~mm}$, diameter of osculum $=1.5 \mathrm{~mm}$. The other dimensions of the aquiferous system (see later) are based on Haliclona permollis derived from Reiswig (1975, Table 1)

Knowing the surface area of the 'standard sponge' $\left(8.65 \mathrm{~cm}^{2}\right)$, the area of osculum $\left(0.018 \mathrm{~cm}^{2}\right)$ and the pumping rate $\left(6 \mathrm{ml} \mathrm{min}^{-1}\right)$ the velocity of water approaching the sponge surface $\left(U_{5}\right)$ and leaving the osculum $\left(U_{\mathrm{e}}\right)$ may be estimated as $U_{\mathrm{s}}=6 /(8.65 \times 60)=$ $0.12 \mathrm{~mm} \mathrm{~s}^{-1}$ and $U_{\mathrm{e}}=6 /(0.018 \times 60)=55.6 \mathrm{~mm} \mathrm{~s}^{-1}$, re- spectively. These values may be compared to $U_{\mathrm{s}}=0.17$ $\mathrm{mm}^{-1}$ and $U_{\mathrm{e}}=51.3 \mathrm{~mm} \mathrm{~s}^{-1}$ found for Haliclona permollis by Reiswig (1975) using time-displaced photographs of ejected particles in the oscular stream to determine the rate of water transport. The agreement is encouraging and supports the 'meager but suggestive approximations' of water transport rates made by Reiswig.

To determine the normal pump pressure or operating point of the 'standard sponge' pump, and subsequently to calculate the pump power output, we need to know the sum of head losses along the flow path through the canal and filter system of the sponge (i.e. the system characteristic). To enable calculation of the head losses we need to know the anatomy of the sponge, including the length and diameter of canals and chambers etc., and flow velocity in the different regions along the flow path. Fluid mechanical calculations in the calcareous sponge Leuconia aspera were made for the first time by Bidder (1923), but during the last 70 yr apparently nobody has tried to get further with the type of calculations presented below.

The aquiferous canal system in the 'standard sponge' may be described as follows (mainly based on Reiswig 1975, see also Fig. 1): water enters the sponge through numerous ostia (mean diameter $=20.6 \mu \mathrm{m}$ ) on the surface and passes through a quickly branching system of narrow inhalant canals (IC) of about 300 then 100 then $50 \mu \mathrm{m}$ diameter, comparable to the branch system of a tree, to the choanocyte chambers (CC, diameter $=30 \mu \mathrm{m})$, which may be considered as the basic pump units. All pump units operate in parallel (see e.g. Kilian 1952, Figs. 9 \& 19; Langenbruch 1983, Fig. 3) at approximately the same flow and pressure rise. The density of CCs is $12000 \mathrm{~mm}^{-3}$ and they constitute a considerable part of the wall structure separating inhalant and exhalant canals (see later). 
Table 3. Velocities of water flow and main contributions to head losses ( $\Delta H$ ) along flow path from entry (ostia) to exit (osculum) in 'standard sponge' (see text) estimated from percent cross-sectional areas and mean diameters (range in brackets) of canal elements in the aquiferous system measured by Reiswig (1975) for Haliclona permollis or calculated in the present work (i.e. mean diameter of inhalant and exhalant canals, see text)

\begin{tabular}{|lcccc|}
\hline Canal element & $\begin{array}{c}\text { Percent of inhalant } \\
\text { surface }\end{array}$ & $\begin{array}{c}\text { Diameter } \\
(\mu \mathrm{m})\end{array}$ & $\begin{array}{c}\text { Velocity } \\
\left(\mathrm{mm} \mathrm{s}^{-1}\right)\end{array}$ & $\begin{array}{c}\Delta \\
\left(\mathrm{mm} \mathrm{H}_{2} \mathrm{O}\right)\end{array}$ \\
\hline Inhalant surface & 100 & - & 0.12 & - \\
Ostia & 30 & $20.6(4.5-44)$ & 0.40 & 0.0373 \\
Apertures of inhalant canals & 10 & $50-340$ & 1.20 & - \\
Inhalant canals (3 mm long) & - & $102-235$ & - & $0.1205-0.013$ \\
Prosopyles & 207 & $1-5$ & 0.06 & $-1153-0.0231$ \\
Choanocyte chambers & - & $30(22-37)$ & - & - \\
Collar bases & 3500 & - & 0.0034 & 0.122 \\
Collar slits & 5600 & 0.11 & 0.015 & - \\
Collar apertures & 810 & - & 0.029 & - \\
Apropyles & 420 & 14 & 4.0 & - \\
Apertures of exhalant canals & 3 & $100-650$ & - & - \\
Exhalant canals (3 mm long) & - & $102-235$ & 23.8 & $0.1205-0.013$ \\
Atrium & - & 2.300 & 55.6 & 0.1576 \\
Osculum & - & 1500 & & Total $0.673-0.366$ \\
& & & & \\
\hline
\end{tabular}

Within each $\mathrm{CC}$ there are 60 to 100 choanacytes, each with a beating flagellum. Water enters the CCs through an inhalant opening (prosopyle) with a diameter of 1 to $5 \mu \mathrm{m}$. The beating flagellum draws water through a 'collar filter' surrounding each flagellum. The collar consists of a circular row of approximately $5 \mu \mathrm{m}$ long and $0.14 \mu \mathrm{m}$ wide fibrils (pseudopodia) with a slit of $0.11 \mu \mathrm{m}$ between adjacent fibrils (i.e. the center distance between fibrils $=0.25 \mu \mathrm{m}$ ). Water flows from the CCs through the exhalant opening (apopyle; diameter $=14 \mu \mathrm{m}$ ) which is surrounded by a ring of cone cells (Langenbruch \& Scalera-Liaci 1985) into a system of exhalant canals (EC), which mirrors the inhalant system. Finally, the water channels of all exhalant systems merge into the atrial cavity which has an exit osculum on the surface through which the filtered water leaves the sponge as a strong jet.

From analysis of microscopic cross-sectional areas of the aquiferous system in Haliclona permollis, Reiswig (1975) estimated the area of the different parts of the canal system. He expressed these areas as a percentage of the inhalant sponge surface as shown in Table 3 , which also contains diameters, velocities of water flow and head losses along the flow path (see next section) calculated for the 'standard sponge' in the present work.

\section{Head losses along flow path}

To verify the consistency of quantitative data of the 'standard sponge', a simple calculation based on the density of CCs of about $12000 \mathrm{~mm}^{-3}$ estimated by Reiswig (1975) will give the average diameter of ICs and ECs. Thus, consider a length $L$ of a canal of inside diameter $D$ and wall thickness equal to the diameter $\left(D_{\mathrm{cc}}=0.030 \mathrm{~mm}\right)$ of the CC. Let the CCs be distributed uniformly over the wall, on a square array of pitch referred to the inside surface, which proves convenient for later analysis (in the Appendix). Then, the number of CCs in this length of canal will be about $\pi D L / l^{2}$ where $l$ is the distance between CCs (a triangular array with the same pitch would give $2 / 3$ times as many $\mathrm{CCs}$ ). The number of $\mathrm{CCs}$ per unit volume (n) becomes $4 D /\left[l^{2}\left(D+2 D_{c c}\right)^{2}\right]$, and the volume fraction of wall structure taken up by CCs becomes $\pi\left(D_{c c} / l\right)^{2} /$ $\left[6\left(1+l / D_{c c}\right)\right]$. Taking $\mathrm{n}=12000 \mathrm{~mm}^{-3}$ and $l=0.030$ and $0.036 \mathrm{~mm}$ yields $D=0.235$ and $0.102 \mathrm{~mm}$, and the cor responding volume fraction of wall taken up by CCs becomes 46 and $28 \%$, respectively. This is in agreement with microscopic cross-sectional observations which show structures where walls between ICs and ECs consist essentially of closely packed CCs (e.g. Kilian 1952).

Though the topology of the 3-dimensional canal system has not yet been determined it appears that litthe of the total volume of the sponge can be allocated to canals larger than those estimated above, but there may be smaller canals. For a canal of diameter $D_{1}$ bifurcating into 2 canals of diameter $D_{2}$ carrying the same total volume flow, we find for Poiseuille flow (Eq. A2 in the Appendix), that $D_{2} / D_{1}=2^{-1 / 4}=0.84$ if the pressure gradient were to be the same, and $D_{2} / D_{1}=$ $2^{-1 / 2}=0.71$ if the velocity were to be the same (yielding 
twice the pressure gradient). To satisfy the high packing of CCs most of the sponge volume must be taken up by relatively small canals of diameter 100 to $200 \mu \mathrm{m}$ that are relatively long, perhaps $3 \mathrm{~mm}$ or longer, in the 'standard sponge' These narrow and long canals contribute significantly to the frictional pressure drop, which will now be estimated.

Using the relations derived in the Appendix on the assumption of a constant pressure gradient along the canal, and taking $Q_{\mathrm{cc}}=4.46 \times 10^{-6} \mathrm{~mm}^{3} \mathrm{~s}^{-1}, L=3 \mathrm{~mm}$, $l=0.030$ and $0.036 \mathrm{~mm}$ and inlet diameter $D_{0}=(4 / 3) D$ $=0.313$ and $0.136 \mathrm{~mm}$, respectively, then $\mathrm{Eq}$. A4 gives a pressure gradient of 0.0047 and $0.0402 \mathrm{~mm} \mathrm{H}_{2} \mathrm{O}(\mathrm{mm}$ canal) $^{-1}$, respectively, and the total frictional pressure drop in a $3 \mathrm{~mm}$ long IC becomes 0.013 and $0.1205 \mathrm{~mm}$ $\mathrm{H}_{2} \mathrm{O}$, respectively. The same pressure drop is found for a $3 \mathrm{~mm}$ EC, (Table 3). Note that the pressure drop for a given canal length depends inversely on $l^{2}$ and $D^{3}$, so it depends critically on the estimate of these parameters. For example, if the inlet diameter were $0.1 \mathrm{~mm}$ instead of $0.136 \mathrm{~mm}$ for $l=0.036 \mathrm{~mm}$, the pressure drop would be $0.606 \mathrm{~mm} \mathrm{H}_{2} \mathrm{O}$. According to Eq. A3 the diameter should decrease from $100 \mu \mathrm{m}$ at the inlet to 79.4 and $46.4 \mu \mathrm{m}$, respectively, 1.0 and $2.7 \mathrm{~mm}$ downstream of the inlet, and should then decrease to zero over the last $10 \%$ of the $3 \mathrm{~mm}$ canal length. Although the actual topology may deviate from the ideal design assumed, it is likely that the latter may be a good approximation over most of the length of ICs and ECs to ensure that most pump units would operate optimally in parallel, that is, at approximately the same pressure rise. Also, as long as the pressure gradient is assumed to be constant, once determined, the total pressure drop depends only on the length of the flow path, whether or not the canal system is branching. Referring to Table 3 , other major contributions to system pressure drop include apertures at ostia and prosopyles, the collar slits and the kinetic energy of the jet leaving the osculum.

The pressure drop for creeping flow with volume flow $Q$ and mean velocity $U$ through a circular aperture of diameter $d$ is obtained from Happel \& Brenner (1965, p.153) as

$$
\Delta H_{\mathrm{ap}}=24 Q \nu /\left(g d^{3}\right)=6 \pi \nu U /(g d)
$$

which gives 0.373 and 0.1153 to $0.0231 \mathrm{~mm} \mathrm{H}_{2} \mathrm{O}$ for ostia and prosopyles, respectively. Now, assume that all flow passes the $0.11 \mu \mathrm{m}$ wide slits between the parallel circular cylinders, the collar fibrils (diameter, $d=$ $0.14 \mu \mathrm{m})$, spaced with a distance $b=(0.25 \mu \mathrm{m})$ between centers of neighbouring cylinders. Then the model developed by Tamada \& Fujikawa (1957) can be used to calculate the pressure drop over the collar filter:

$$
\Delta H=K v u /(g d)
$$

where $K=8 \tau /\left(1-2 \ln \tau+\tau^{2} / 6\right), \tau=\pi(d / b)$, u is the unrestricted upstream flow velocity $\left(0.0034 \mathrm{~mm} \mathrm{~s}^{-1}\right.$ at $12{ }^{\circ} \mathrm{C}$ ). The calculated pressure drop is found to be $0.122 \mathrm{~mm} \mathrm{H}_{2} \mathrm{O}$, see Table 3. Finally, the high exit velocity from oscula, $U_{\mathrm{e}}=55.6 \mathrm{~mm} \mathrm{~s}^{-1}$, gives a sizeable contribution, $U_{\mathrm{e}}{ }^{2} /(2 \mathrm{~g})=0.1576 \mathrm{~mm} \mathrm{H}_{2} \mathrm{O}$. Thus, adding all the significant contributions, listed in Table 3 , the total system pressure drop becomes about 0.366 to $0.673 \mathrm{~mm} \mathrm{H}_{2} \mathrm{O}$ at $12{ }^{\circ} \mathrm{C}$.

\section{Pump work}

The normal operating point $O_{p}$ of the 'standard sponge' is defined by the total head loss along the flow path, i.e. 0.366 to $0.673 \mathrm{~mm} \mathrm{H}_{2} \mathrm{O}$, see Table 3. The maximum power output $P_{\mathrm{p}}$ can be calculated as pumping pressure $\left(\Delta P=\rho g O_{p} ; O_{p}=0.673 \mathrm{~mm} \mathrm{H}_{2} \mathrm{O}\right)$ multiplied by the pumping rate $\left(F=6 \mathrm{ml} \mathrm{min}^{-1}\right)$, resulting in a $P_{\mathrm{p}}=0.677 \mu \mathrm{W}$. With a respiration rate $R=15 \mu \mathrm{l} \mathrm{O}$ $\mathrm{h}^{-1}$, equivalent to $80 \mu \mathrm{W}$, the 'pump work' $P_{\mathrm{p}} / R=$ $0.677 / 80=0.85 \%$.

\section{Comparison with other suspension feeders}

\section{Temperature effects}

In recent years the effect of temperature on filtration rate has been studied in several ciliary suspension feeders. In Table 4 the temperature effect on filtration rate in Halichondria panicea \#8, \#9 and \#10 is compared with other ciliary suspension feeders. The mean increase in filtration rate of $H$. panicea when the temperature was increased from 6 to $12^{\circ} \mathrm{C}$ was $4.3 \pm 2.3$ times. This increase may be compared to $2.7 \pm 0.3$ in the ascidian Ciona intestinalis, $1.4 \pm 0.1$ in the mussel Mytilus edulis and $1.2 \pm 0.2$ times in the polychaete Sabella penicillus. The temperature effect was thus most pronounced in the sponge, but also more illdefined. Obviously there is no common temperaturedependent factor controlling the filtration rate in these ciliary suspension feeders. In $M$. edulis and $S$. penicillus the variation in filtration rate could be explained solely by the temperature-dependent changes in viscosity (Jørgensen et al. 1990, Riisgård \& Ivarsson 1990); but not in C. intestinalis (Petersen \& Riisgård 1992) where a substantial effect of increased ciliary activity with temperature was suggested. The very pronounced increase in $H$. panicea cannot be explained by a combined effect of change in viscosity and change of beat frequency of the choanocyte flagella. The $Q_{10}$ for filtration rate in Sponges \#8, \#9 and \#10 was 4.2, 25 and 8.7 , respectively. Because $Q_{10}$ is usually between 2 and 3 for biological processes (including flagellar beat 
Table 4. Effect of temperature on filtration rate in various ciliary filter-feeding invertebrates

\begin{tabular}{|c|c|c|c|}
\hline Species & \multicolumn{2}{|c|}{$\begin{array}{l}\text { Filtration rate }\left(\mathrm{ml} \mathrm{min}^{-1}\right) \\
\begin{array}{ll}\text { at } 6{ }^{\circ} \mathrm{C} & \text { at } 12^{\circ} \mathrm{C}\end{array}\end{array}$} & $12^{\circ} \mathrm{C} / 6^{\circ} \mathrm{C}$ \\
\hline \multicolumn{4}{|c|}{ Halichondria panicea (present work) } \\
\hline Sponge \#8 & 11.4 & 26.8 & 2.4 \\
\hline Sponge \#9 & 2.9 & 20.0 & 6.9 \\
\hline \multirow[t]{2}{*}{ Sponge \#10 } & 7.0 & 25.7 & 3.7 \\
\hline & \multicolumn{2}{|r|}{ Mean \pm SD } & $4.3 \pm 2.3$ \\
\hline \multicolumn{4}{|c|}{ Ciona intestinalis (Petersen \& Riisgård 1992, Table 2) } \\
\hline 1 & 3.6 & 10.3 & 2.9 \\
\hline 2 & 4.0 & 11.9 & 3.0 \\
\hline 3 & 4.9 & 12.9 & 2.6 \\
\hline 4 & 7.6 & 19.0 & 2.5 \\
\hline 5 & 8.2 & 18.0 & 2.2 \\
\hline \multirow[t]{2}{*}{6} & 4.6 & 13.5 & 2.7 \\
\hline & \multicolumn{2}{|r|}{ Mean $\pm S D$} & $2.7 \pm 0.3$ \\
\hline \multicolumn{4}{|c|}{ Mytilus edulis (Jørgensen et al. 1990, Fig. 2) } \\
\hline May & 42 & 53 & 1.3 \\
\hline February & 28 & 38 & 1.4 \\
\hline \multirow[t]{2}{*}{ June } & \multirow{2}{*}{\multicolumn{2}{|c|}{ Mean \pm SD }} & 1.5 \\
\hline & & & $1.4 \pm 0.1$ \\
\hline \multicolumn{4}{|c|}{ Sabella penicillus (Riisgård \& Ivarsson 1990, Eq. 1, Fig. 6) } \\
\hline $\mathrm{Eq} \cdot 1$ & 102 & 114 & 1.1 \\
\hline I & 36 & 49 & 1.4 \\
\hline \multirow[t]{2}{*}{ II } & 51 & 61 & 1.2 \\
\hline & & Mean \pm SD & $1.2 \pm 0.2$ \\
\hline
\end{tabular}

frequency), the acute temperature effect in sponges may also be partly determined by factors such as constriction/dilation of inhalant canals and/or choanocyte chambers, particularly because such constrictions have been observed in Ephydatia fluviatilis by Wintermann (cited by Kilian 1952, Fig. 16). Even the ring of coneshaped cells in the apopyle region (Langenbruch \& Scalera-Liaci 1990) and the porocytes in the pinacoderm (Harrison 1972) may be temperature-dependent sites determining water flow.

\section{Energy cost of filtration}

Operation point, power output and pump work have recently been determined in a number of different suspension-feeding animals (for a summary see Table 3 in Riisgård \& Ivarsson 1990). The operating point $\left(O_{p}\right)$ of the ciliary pumps of mussels (Mytilus edulis), polychaetes (Sabella penicillus) and ascidians (Styela clava) has been estimated as $1.0,0.0224$ and $0.3 \mathrm{~mm}$ $\mathrm{H}_{2} \mathrm{O}$, respectively, and pump work $\left(P_{\mathrm{p}} / R\right)$ as $1,1,0.403$ and $0.26 \%$, respectively. In the present investigation $O_{\mathrm{p}}=0.673$ and $P_{\mathrm{p}} / R=0.85 \%$ in the 'standard sponge'
Thus, the sponge pump has properties comparable with other ciliary suspension feeders, the energy cost of water pumping being low in all cases.

It may be of interest to evaluate the head losses, and thus the energy cost of pumping water through the different parts of the sponge aquiferous system (Table 3 ). The pressure drop in the prosopyles may be considerable if there is only 1 prosopyle with a small opening, down to $1 \mu \mathrm{m}$ in diameter as suggested by Reiswig (1975); but in Haliclona elegans and other marine haplosclerids, Langenbruch \& Scalera-Liaci (1990) have found several prosopyles per choanocyte chamber. The pressure drop found for prosopyles in the present work may therefore be considerably overestimated. The head loss at the osculum is pronounced and may reflect how important it is for the sponges to create a strong jet of exhalant water to prevent recirculation of pre-filtered water. This may also be reflected in the chimney-like extensions bearing the output openings in many sponges. Such extensions have also been interpreted as devices for current-induced flow through the sponge, thus increasing the filtration rate without direct metabolic cost (Vogel 1978a, b). The generaily low energy cost of filtration in sponges (which may also live in calm water) makes it likely that passive current-induced filtration may be relatively unimportant in sponges.

Acknowledgements. Thanks are due to Morten Helholm for diving and to Marianne Holmer for help with CHN analyses Prof. C. Barker Jørgensen passed remarks on the manuscript. and Drs Dagmar Barthel and Ole S. Tendal made a number of critical comments on an early version of the manuscript, the latter is also acknowledged for determining the names of the sponges.

\section{LITERATURE CITED}

Barthel, D. (1988). On the ecophysiology of the sponge Halichondria panicea in Kiel Bight. II. Biomass, production, energy budget and integration in environmental processes. Mar. Ecol. Prog. Ser. 43: 87-93

Barthel, D., Theede, H. (1986). A new method for the culture of marine sponges and its application for experimental studies. Ophelia 25: 75-82

Bergquist, P. R. 11978). Sponges. University of California, Berkeley

Bidder, G. P. (1923). The relation of the form of a sponge to its currents. Q. J. microb. Sci. 67: 293-323

Fenchel, T (1986). Protozoan filter feeding. Prog. Protistol 1. $65-113$

Foster-Smith, R. L. (1976). Pressures generated by the pumping mechanism of some ciliary filter-feeders. J. exp. mar Biol. Ecol. 25: 199-206

Fox, R. W., McDonald, A. T (1985). Introduction to fluid mechanics. John Wiley \& Sons, New York

Frost, T. M. (1978). In situ measurements of clearance rates for the freshwater sponge Spongilla lacustris. Limnol. Oceanogr. 23: 1034-1039 


\section{Appendix}

Consider an inhalant canal of circular cross section with a slowly decreasing diameter $D(x)$. The wall is composed of CCs, each having volume flow $Q_{\mathrm{cc}}$ and being uniformly spaced $1 \mathrm{~mm}$ apart. Then the volume flow leaving the canal per unit length becomes

$$
\delta Q / \delta L=Q_{\ulcorner\Gamma} \pi D / 1^{2}
$$

The local pressure gradient $\left(\delta H_{f} / \delta L\right)$ along the canal due to friction, assuming quasi-developed Poiseuille flow, is, expressed as hydrostatic head (Fox \& McDonald 1985, p. 360),

$$
\delta H_{\mathrm{f}} / \delta L=32 \vee U / g D^{2}=128 \vee Q /\left(g \pi D^{4}\right)
$$

where $U$ denotes the mean velocity, $v=\mu / \rho$ the kinematic viscosity, $\mu$ the dynamic viscosity, $\rho$ the density, and $g$ the acceleration of gravity. Now, assuming the pressure gradient to be constant, using the conservation of volume flow $Q$ $=U \pi D^{2} / 4$ and Eqs.(A1) $-(\mathrm{A} 2)$, leads to a differential equation for the variation of the diameter $D(x)$ along the canal. The solution to this equation may be written

$$
D / D_{0}=(1-x / L)^{1 / 3}
$$

where $D_{0}$ denotes the inlet diameter and $L$ the total canal length, which is related to other parameters by

$$
L=\left(\delta H_{\mathrm{f}} / \delta L\right) g l^{2} D_{0}{ }^{3} /\left(96 Q_{\mathrm{Cc}} \vee\right)
$$

Finally, integration of Eqs. A1, using A3, gives the volume flow at the inlet

$$
Q_{0}=(3 / 4) Q_{C C} \pi D_{0} L / l^{2}
$$

It is readily shown from Eq. A3 that the mean canal diameter, based on surface area, hence on number of CCs, is $3 / 4$ of the inlet diameter. Also, the foregoing analysis applies equally to an $\mathrm{EC}$, reference now being made to the exit instead of the inlet. In reality, however, canals cannot be of circular cross section if they are to fill the volume of the sponge, but the foregoing analysis still applies, with constants adjusted for other geometries.
Frost, T. M. (1980). Clearance rate determinations for freshwater sponge Spongilla lacustris: effects of temperature, particle type and concentration, and sponge size. Arch. Hydrobiol. 90: 330-356

Happel, J., Brenner, H. (1965). Low Reynolds number hydrodynamics. Prentice-Hall, Inc., Englewood Cliffs

Harrison, F. W. (1972). Phase contrast photomicrography of cellular behaviour in spongillid porocytes (Porifera: Spongillidae). Hydrobiologia 40: 513-517

Jergensen, C. B. (1949). Feeding-rates of sponges, lamellibranchs and ascidians. Nature 163: 912-913

Jorgensen, C. B. (1955). Quantitative aspects of filter feeding in invertebrates. Biol. Rev. 30: 391-454

Jørgensen, C. B. (1966). Biology of suspension feeding. Pergamon Press, Oxford

Jorgensen, C. B. (1975). Comparative physiology of suspension feeding. A. Rev. Physiol. 37: 57-79

Jorgensen, C. B. (1983). Fluid mechanical aspects of suspension feeding. Mar. Ecol. Prog. Ser. 11: 89-103

Jørgensen, C. B., Kiørboe, T., Møhlenberg, F., Riisgård, H. U. (1984). Ciliary and mucus net filter feeding, with special reference to fluid mechanical characteristics. Mar. Ecol. Prog. Ser. 15: 283-292

Jørgensen, C. B., Larsen, P. S., Møhlenberg, M., Riisgård, H. U. (1988). The bivalve pump: properties and modelling. Mar. Ecol. Prog. Ser. 45: 205-216

Jørgensen, C. B., Larsen, P. S., Riisgård, H. U. (1990). Effects of temperature on the mussel pump. Mar. Ecol. Prog. Ser. 64: 89-97

Jørgensen, C. B., Riisgård, H. U. (1988). Gill pump characteristics of the soft clam Mya arenaria. Mar. Biol. 99: $107-109$

Kilian, E. F. (1952). Wasserströmung und Nahrungsaufnahme beim Süsswasserschwamm Ephydatia fluviatilis. Z. vergl. Physiol. 34: 407-447

LaBarbera, M. (1984). Feeding currents and particle capture mechanisms in suspension feeding animals. Am. Zool. 24: $71-84$

Langenbruch, P.-F. (1983). Untersuchungen zum Körperbau von Meeresschwämmen. II. Das Wasserleitungssystem von Halichondria panicea. Helgoländer Meeresunters. 36: $337-346$

Langenbruch, P.-F., Scalera-Liaci, L. (1990). Structure of choanocyte chambers in haplosclerid sponges. In: Rützler, $\mathrm{K}$. (ed.) New perspectives in sponge biology. Papers contributed to the 3rd International Conference on the Biology of Sponges. Smithsonian Institution Press, Washington, DC, p. 245-251

Petersen, J. K., Riisgård, H. U. (1992). Filtration capacity of the ascidian Ciona intestinalis (L.) and its grazing impact in a shallow fjord. Mar. Ecol. Prog Ser. 88: 9-17

Reiswig, H. M. (1971). Particle feeding in natural populations of three marine demosponges. Biol. Bull. 141: 568-591

Reiswig, H. M. (1974). Water transport, respiration and energetics of three tropical marine sponges. J. exp. mar Biol. Ecol. 14: 231-249

Reiswig, H. M. (1975). The aquiferous systems of three marine demospongiae. J. Morph. 145: 493-502

Riisgård, H. U. (1988). The ascidian pump: properties and energy cost. Mar. Ecol. Prog. Ser. 47: 129-134

Riisgård, H. U. (1989). Properties and energy cost of the muscular piston pump in the suspension feeding polychaete Chaetopterus variopedatus. Mar. Ecol. Prog. Ser. 56: $157-168$

Riisgård, H. U., Ivarsson, N. M. (1990). The crown-filamentpump of the suspension-feeding polychaete Sabella penicillus: filtration, effects of temperature, energy cost, and modelling. Mar. Ecol. Prog. Ser. 62: 249-257

Riisgård, H. U., Randløv, A., Sand Kristensen, P. (1980). Rates of water processing oxygen consumption and efficiency of particle retention in veligers and young post-metamorphic Mytilus edulis. Ophelia 19: 37-47

Riisgård, H. U., Vedel, A., Boye, H., Larsen, P. S. (1992). Filternet structure and pumping activity in the polychaete Nereis diversicolor: effects of temperature and pumpmodelling. Mar. Ecol. Prog. Ser. 83: 79-89

Simpson, T. L. (1984). The cell biology of sponges. SpringerVerlag, New York 
Tamada, K., Fujikawa, H. (1957). The steady two-dimensional flow of viscous fluid at low Reynolds numbers passing through an infinite sow of equal parallel circular cylinders. Q. J. Mech. appl. Math. 10:426-432

This article was submitted to the editor
Vogel, S. (1978a). Organisms that capture currents. Sci. Am. 239: $108-117$

Vogel, S. (1978b). Evidence for one-way valves in the waterflow system of sponges. J. exp. Biol. 76 : 137-148

Manuscript first received: January 19, 1993

Revised version accepted: March 15, 1993 